\title{
Association between domestic violence and oral health problems in children and adolescents: a systematic review
}

Associação entre violência doméstica e problemas de saúde bucal em crianças e adolescentes: revisão sistemática Asociación entre violencia doméstica y problemas de salud bucal en niños y adolescentes: revisión sistemática Michele Gomes do NASCIMENTO ${ }^{1}$ Nataly Pereira da COSTA ${ }^{2}$ Viviane COLARES ${ }^{3}$

${ }^{1} M S$, Department of Pediatric Dentistry, Division of Pediatric Dentistry, University of Pernambuco, Recife-PE, Brazil ${ }^{2}$ Department of Dentistry, Division of Hebiatrics, University of Pernambuco, Recife-PE, Brazil ${ }^{3}$ Department of Pediatric Dentistry, Division of Pediatric Dentistry, University of Pernambuco, Recife-PE, Brazil; Department of Preventive and Clinical Dentistry, Federal University of Pernambuco, Recife - PE, Brazil

\section{Abstract}

Domestic violence has a negative impact on development, general health, and quality of life of children and adolescents. This study aimed to revise knowledge regarding the consequences on oral health and its related outcomes of children and adolescents exposed to domestic violence. We conducted this systematic review in line with Preferred Reporting Items for Systematic Review and Meta-Analyses (PRISMA) statement, adhering to a published protocol in PROSPERO. This review systematically searched the literature using the MEDLINE, PsycINFO, LILACS, SciELO databases and Grey Literature, for articles published in English, Portuguese, and Spanish, with no publication date limits. Quality of studies was assessed using New Castle Ottawa scale and its modified version. All process was carried out independently by two researchers. Fourteen studies were included. Nine studies were cross-sectional, four were case-control, and one was a retrospective cohort. All studies included in this review found a higher risk of having some oral health problem and being exposed to some type of domestic violence. The main oral health problems associated with some type of violence were caries experience (decayed, missing and filled teeth), poor self-perceived oral health, malocclusion, poorer oral health related quality of life, poorer oral hygiene, and early childhood caries experience. Important methodological advancements are needed to better understand potential moderators.

Descriptors: Child; Adolescent; Oral Health; Domestic Violence; Child Abuse.

Resumo

A violência doméstica tem um impacto negativo no desenvolvimento, saúde geral e qualidade de vida de crianças e adolescentes. Este estudo teve como objetivo revisar o conhecimento sobre as consequências na saúde bucal e seus desfechos em crianças e adolescentes expostos à violência doméstica. Conduzimos esta revisão sistemática de acordo com a declaração de itens de relatório preferidos para revisão sistemática e meta-análises (PRISMA), aderindo a um protocolo publicado no PROSPERO. Esta revisão buscou sistematicamente a literatura nas bases de dados MEDLINE, PsycINFO, LILACS, SciELO e Grey Literature, para artigos publicados nos idiomas inglês, português e espanhol, sem limite de data de publicação. A qualidade dos estudos foi avaliada usando a escala de New Castle Ottawa e sua versão modificada. Todo o processo foi realizado de forma independente por dois pesquisadores. Quatorze estudos foram incluídos. Nove estudos eram transversais, quatro eram de caso-controle e um era uma coorte retrospectiva. Todos os estudos incluídos nesta revisão encontraram maior risco de ter algum problema de saúde bucal e ficar exposto a algum tipo de violência doméstica. Os principais problemas de saúde bucal associados a algum tipo de violência foram experiência de cárie (dentes cariados, perdidos e obturados), autopercepção de saúde bucal precária, má oclusão, pior qualidade de vida relacionada à saúde bucal, higiene bucal precária e experiência de cárie na primeira infância. Avanços metodológicos importantes são necessários para entender melhor os moderadores em potencial.

Descritores: Criança; Adolescente; Saúde Bucal; Violência Doméstica; Maus-Tratos Infantis.

\section{Resumen}

La violencia doméstica tiene un impacto negativo en el desarrollo, la salud general y la calidad de vida de los niños y adolescentes. Este estudio tuvo como objetivo revisar el conocimiento sobre las consecuencias sobre la salud bucal y sus resultados relacionados de los niños y adolescentes expuestos a la violencia doméstica. Realizamos esta revisión sistemática de acuerdo con la declaración Preferred Reporting Items for Systematic Review and Meta-Analyzes (PRISMA), siguiendo un protocolo publicado en PROSPERO. Esta revisión buscó sistemáticamente la literatura utilizando las bases de datos MEDLINE, PsycINFO, LILACS, SciELO y Grey Literature, para artículos publicados en inglés, portugués y español, sin límites de fecha de publicación. La calidad de los estudios se evaluó mediante la escala de New Castle Ottawa y su versión modificada. Todo el proceso fue realizado de forma independiente por dos investigadores. Se incluyeron catorce estudios. Nueve estudios fueron transversales, cuatro fueron de casos y controles y uno fue una cohorte retrospectiva. Todos los estudios incluidos en esta revisión encontraron un mayor riesgo de tener algún problema de salud bucal y estar expuesto a algún tipo de violencia doméstica. Los principales problemas de salud bucal asociados con algún tipo de violencia fueron la experiencia de caries (dientes cariados, perdidos y obturados), mala salud bucal autopercibida, maloclusión, peor calidad de vida relacionada con la salud bucal, peor higiene bucal y experiencia de caries en la primera infancia. Se necesitan avances metodológicos importantes para comprender mejor a los posibles moderadores.

Descriptores: Niño; Adolescente; Salud Bucal; Violencia Doméstica; Maltrato a los Niños.

\section{INTRODUCTION}

Oral health is an important part of general health and contributes to children's and adolescents' quality of life. Neglecting oral health produces negative consequences for children's development, self-perceived oral and general health, and quality of nutrition ${ }^{1-3}$. Oral diseases, particularly dental caries, have a complex and interconnected etiology with common, primarily behavioral based risk factors.
The main individual key factors are a sugar-rich diet in combination with an insufficient oral hygiene and inappropriate fluoride exposure ${ }^{4}$. Undeniably, a diversity of oral health problems may occur among children and adolescents, some of them may initiate during childhood and persist into adulthood ${ }^{1,5}$. Studies on children's oral health report malocclusion as a worldwide dental problem that influences the 
affected individuals in several degrees. Dental caries, pulpal and periapical lesions, dental trauma, abnormality of development, and oral habits are the most common dental diseases in children $^{1,6,7}$. Adverse experiences, such as abuse and neglect, physical and psychological violence, are identified as situations harmful to the victim's health ${ }^{8-10}$. Children and adolescents exposed to such experiences are more likely to have toothache, cavities, among other dental problems, compared to those who are not exposed ${ }^{8,11}$.

The World Health Organization defines violence as the use of physical power against another individual, who may cause some type of injury or damage, physical or psychological. Physical, sexual, emotional abuse and neglect are recognized as domestic violence ${ }^{12}$. Some physical evidences generated by domestic violence are more easily observed in the orofacial complex, becoming eventually detected by dentists ${ }^{13}$. Therefore, this review aims to investigate if there is an association between exposure to domestic violence during childhood and/or adolescence and its impact on oral health.

MATHERIAL AND METHOD

- Registration and protocol

We conducted this systematic review in line with Preferred Reporting Items for Systematic Review and Meta-Analyses (PRISMA) statement (Moher et al. 2009) ${ }^{14}$, adhering to a published protocol in PROSPERO (ref. CRD42015029874). The PECO methodology was utilized to formulate the research question: "Is there an association between exposure to domestic violence and detrimental outcomes on oral health in children and adolescents?".

\section{- Search method and selection procedure}

Is exposure to domestic violence a risk or associated factor for direct and indirect consequences on oral health of children and adolescents? Does exposure to different types of domestic violence during childhood and adolescent years (0-19) affects oral health status, oral health related quality of life and selfperceived oral health? PECO: Population: children and adolescents, from birth to 19 years of age; Exposure: domestic violence; Comparator: non-applicable; Outcomes: primary - oral health status secondary: oral health related quality of life and self-perceived oral health.

\section{- Eligibility criteria}

We included the following: observational studies (cohort, cross-sectional, or case-control studies), children and adolescents up to 19 years of age, or adults followed retrospectively; investigating factors mediating or moderating the association between exposure to DV and oral health status in children and adolescents; validated measures or data extracted from databases assessing different oral health conditions (caries, malocclusion, periodontal diseases); published in English, Portuguese or Spanish. We excluded review studies (narrative or systematic), letters to the editor, case reports, laboratory studies in animals, studies that did not discriminate the age of the patients, samples with special patients and/or specific group, and studies in which they did not correlate violence and oral health in the age group selected.

- Search strategy

This review systematically searched the literature using the MEDLINE, PsycINFO, LILACS, SciELO databases and Grey Literature by date of inception to August 2019. There no limits on publication date. The PubMed MEDLINE search strategy is included as an example: ((("intimate partner violence"[MeSH Terms] OR ("intimate"[All Fields] AND "partner"[All Fields] AND "violence"[All Fields]) OR "intimate partner violence"[All Fields]) OR ("domestic violence"[MeSH Terms] OR ("domestic"[All Fields] AND "violence"[All Fields]) OR "domestic violence"[All Fields])) AND (("adolescent"[MeSH Terms] OR "adolescent"[All Fields]) OR ("child"[MeSH Terms] OR "child"[All Fields]))) AND ("oral health"[MeSH Terms] OR ("oral"[All Fields] AND "health"[All Fields]) OR "oral health"[All Fields]). Following full-text review, reference and citation lists of included articles hand searched for further relevant studies.

- Data extraction (selection and coding) Initially, records screened based on titles and abstracts against the eligibility criteria by two reviewers (MN and NC). Remaining records full-text review (MN and NC), and a Cohen's kappa were computed to assess the level of agreement between reviewers. Two independent reviewers ( $\mathrm{MN}$ and $\mathrm{NC}$ ) performed data extraction. Studies data were typed in an excel template. Data extracted: first author; year of publication; country; study design; sampling approach; sample size; sample characteristics (age mean and SD or range, \%female/male); Type of domestic violence assessed; measure(s) of exposure to childhood adverse experiences (OR, RR or PR); statistical method used; covariates included in analysis; results.

- Quality assessment

Two reviewers performed a search strategy and did a risk for a bias and a quality assessment of case-control studies using the 
Newcastle-Ottawa quality scale. For cohort and cross-sectional studies, the reviewers applied the Modified Newcastle-Ottawa. In case of doubt a third reviewer assessed as well. The following criteria were used: sample representativity, sample size, non-respondent rate, exposure determination, control of exposure confounding factors, outcome assessment, and statistical test used. Each item could mark up to 1 point. Studies' quality was rated on a scale from 0 (high risk of bias) to 9 (low risk of bias). Disagreements between the reviewers in relation to quality assessment were resolved by consensus.

\section{- Strategy for data synthesis}

A narrative synthesis was planned in the first instance - summaries of sample characteristics, study design, methods used, and the type of childhood adversity experienced presented results of the included studies. Data synthesis were carried out by two reviewers (NC and $\mathrm{MN}$ ), with disagreements resolved through consensus with a third reviewer (VC).

RESULTS

\section{- Study selection}

Figure $1^{14}$ describes the results of the search and the study selection process. Following the removal of duplicates, we identified a total of 53 articles. After initial screening based on titles and abstracts, 29 articles remained for further evaluation of eligibility. After inspection of these articles, 15 were excluded because violence was studied mostly in an adult population. This resulted in 14 studies included for the review ${ }^{5,8,10,15-24 ~ 22-24}$.

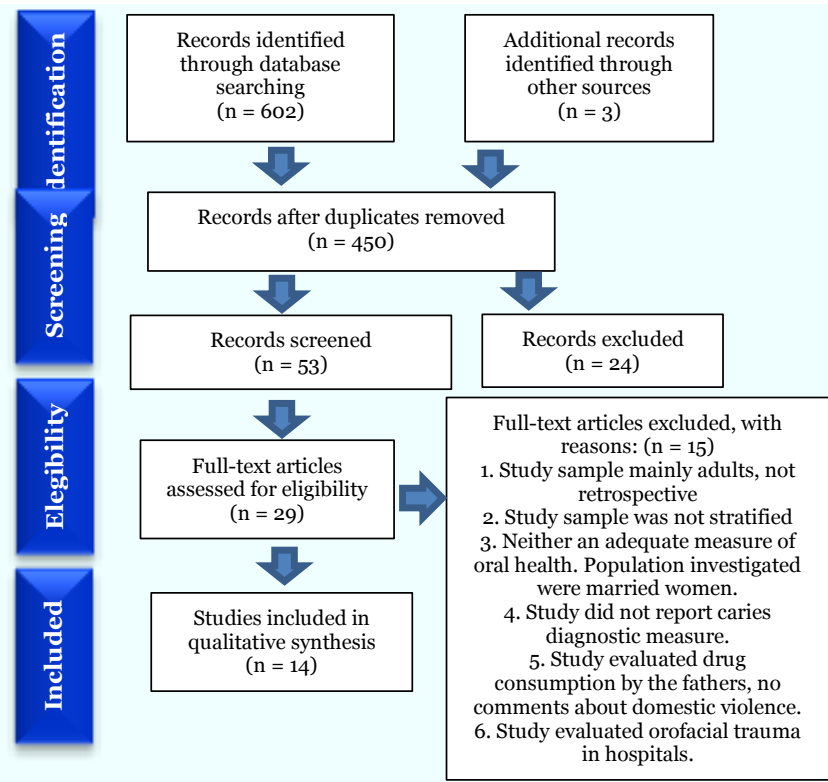

Figure 1. PRISMA flowchart of studies selection.

\section{- Characteristics of the included studies}

A description of the 14 included studies

is provided in Table 1. The country with the largest number of studies was the USA ${ }^{8,15,25-27}$ three in Brazil ${ }^{5,19,21}$ two in Sweden ${ }^{18,22}$; one in India ${ }^{20}$; one in $\mathrm{Canada}^{23}$; one in the $\mathrm{UK}^{16}$ and one in Netherlands ${ }^{10}$. Most studies were crosssectional $^{5,8,10,18-20,22,23,27}$, investigated domestic violence in children and/or adolescents, some $e^{8,10,22,23}$ of them retrospectively. Only one study $^{25}$ was a prospective cohort, using a sample of adults exposed to violence.

\begin{tabular}{|c|c|}
\hline \multicolumn{2}{|c|}{ Cases/ Controls $\quad$ Case Control Studies } \\
\hline Study/year & Greene et al. (1994) ${ }^{19}$ \\
\hline Origin & USA \\
\hline Sample (N) & $30 / 873$ \\
\hline Age group (years) & $5-13$ \\
\hline Type of violence assessed & Abuse/ Neglect \\
\hline Assessment of oral health & DMFS \\
\hline Main Outcomes & $\begin{array}{l}\text { The odds that abused/neglected children have untreated, } \\
\text { decayed teeth are } 8.0 \text { times greater. }\end{array}$ \\
\hline Study/year & Greene et al. (1995) ${ }^{18}$ \\
\hline Origin & USA \\
\hline Sample (N) & $42 / 822$ \\
\hline Age group (years) & 3-11 \\
\hline Type of violence assessed & Abuse/Neglect \\
\hline Assessment of oral health & $\mathrm{dmft}$ \\
\hline Main Outcomes & $\begin{array}{l}\text { Abused/neglected children from military families with } \\
\text { non-combatant sponsors were } 5.2 \text { times more likely to } \\
\text { have untreated decayed primary teeth than children from } \\
\text { other military households. }\end{array}$ \\
\hline Study/year & Duda et al. (2017) ${ }^{26}$ \\
\hline Origin & Brazil \\
\hline Sample (N) & $122 / 240$ \\
\hline Age group (years) & $3-15$ \\
\hline Type of violence assessed & Abuse \\
\hline Assessment of oral health & DMFT, dmft and malocclusion \\
\hline Main Outcomes & $\begin{array}{l}\text { The number of missing teeth was significantly higher in } \\
\text { the case group than in the control group }(\mathrm{P}=\mathrm{O} \text {.04) } \mathrm{A} \\
\text { significant difference was found in the mean DMFT } \\
\text { between groups }(\mathrm{P}<\mathrm{O} \text {.001), in which the case group had } \\
\text { a higher mean DMFT than controls. The case group also } \\
\text { had more untreated decayed teeth than the control group. }\end{array}$ \\
\hline Study/year & Keene et al. $(2015)^{20}$ \\
\hline Origin & UK \\
\hline Sample (N) & $79 / 79$ \\
\hline Age group (years) & $2-11$ \\
\hline Type of violence assessed & Physical abuse, emotional abuse, sexual abuse, or neglect. \\
\hline Assessment of oral health & DMFT, dmft \\
\hline Main Outcomes & $\begin{array}{l}\text { Children with child protection plans had statistically } \\
\text { higher levels of primary tooth decay than controls }(\mathrm{P}= \\
\text { o.002). In this model, the incidence rate ratio (IRR) for } \\
\text { the occurrence of dental caries in primary teeth in } \\
\text { children with a child protection plan was } 1.76 \text { ( } 95 \% \text { CI: } \\
1.44-2.15) \text {. }\end{array}$ \\
\hline \multicolumn{2}{|r|}{ Retrospective Cohort Study } \\
\hline Study/year & Widom et al. (2012) ${ }^{27}$ \\
\hline Origin & USA \\
\hline Sample (N) & 908 cases from 1967 to $1971 / 667$ controls \\
\hline Age group (years) & Average 41.2 \\
\hline Type of violence assessed & Physical abuse, sexual abuse, and neglect \\
\hline Assessment of oral health & Suspicious gums problems or diseases \\
\hline Main Outcomes & $\begin{array}{l}\text { Neglect increased risk for oral health problems }(\mathrm{OR}= \\
1.55 ; 95 \% \mathrm{CI}=1.10,2.18) \text {. }\end{array}$ \\
\hline \multicolumn{2}{|r|}{ Cross-Sectional Studies } \\
\hline Study/year & Valencia-Rojas et al. (2008) ${ }^{17}$ \\
\hline Origin & Canada \\
\hline Sample (N) & 66 \\
\hline Age group (years) & $2-6$ \\
\hline Type of violence assessed & Children suffering maltreatment (abuse, neglect) \\
\hline Assessment of oral health & ECC \\
\hline \multirow[t]{2}{*}{ Main Outcomes } & $\begin{array}{l}\text { Neglect increased risk for oral health problems }(\mathrm{OR}= \\
1.55 ; 95 \% \mathrm{CI}=1.10,2.18) \text {. }\end{array}$ \\
\hline & $\begin{array}{l}\text { ECC was observed in } 58 \text { percent of the abused children. } \\
\text { Logistic regression revealed that children in permanent } \\
\text { CAST (OR: 0.16) care and those in its care (OR: o.14) } \\
\text { more than once were significantly less likely to have } \\
\text { experienced caries. ( } p=0.03 \text { ) }\end{array}$ \\
\hline Study/year & Kvist et al. (2013) ${ }^{22}$ \\
\hline Origin & Sweden \\
\hline Sample (N) & 5,890 \\
\hline Age group (years) & $15-17$ \\
\hline Type of violence assessed & $\begin{array}{l}\text { Child physical abuse, intimate partner violence forced sex } \\
\text { and bullying. }\end{array}$ \\
\hline Assessment of oral health & Poor self-perceived oral health \\
\hline Main Outcomes & $\begin{array}{l}\text { Poor self-perceived oral health was associated with self- } \\
\text { reported experience of physical abuse, intimate partner } \\
\text { violence, forced sex, and bullying (adjusted OR }=2.3- \\
\text { 14.7). The likelihood of reporting poor oral health } \\
\text { increased from an adjusted OR of } 2.1 \text { for a single incident } \\
\text { of abuse to an adjusted OR of } 23.3 \text { for multiple abuses. }\end{array}$ \\
\hline
\end{tabular}

DMFt /dmft: index or decayed, missing, and filled teeth/same for deciduous; DMFS: decayed, missing, and filling surfaces; ECC: early childhood caries; ACEs: adverse childhood experiences. 
Table 1 (Continuation). Summary of studies included

\begin{tabular}{|l|}
\hline Study/year \\
\hline Origin \\
\hline Sample (N) \\
\hline Age group (years) \\
\hline Type of violence assessed \\
\hline Assessment of oral health \\
\hline Main Outcomes \\
\hline \\
\hline Study/year \\
\hline Origin \\
\hline Sample (N) \\
\hline Age group (years) \\
\hline Type of violence assessed \\
\hline Assessment of oral health \\
\hline Main Outcomes \\
\\
\\
\hline Study/year \\
\hline Origin \\
\hline Aample (N) \\
\hline Tge group (years) \\
\hline Asse of violence assessed \\
\hline Main Outcomes \\
\hline
\end{tabular}

Cross-Sectional Studies

Lourenço et al. $(2013)^{2}$

Brazil

149

5 Physical neglect

dmf-t

Associations were found between caries experience and reason of the last consultation $(P=0.011)$, decayed teeth and child's oral health perception $(P=0.001)$. There was a trend towards a significant association between general health and decayed teeth $(P=0.079)$, general hygiene and caries experience $(P=0.083)$, and caries experience and number of times brushes the teeth $(P=0.086)$. Bright et al. (2014) 4

USA 55

ACEs (Child's exposure to the divorce of a parent, parental incarceration, domestic violence, neighborhood) violence, drug and alcohol abuse, mental illness, and financial hardship)

Questions to parents measuring child's oral health

There was a graded association between number of ACEs and likelihood of caregiver report of having teeth in fair or poor condition. Children whose parents reported more than one ACE were $1.35-1.65$ times more likely to have parent-reported teeth in fair or poor condition. Children who experienced more than one ACE were $1.38-2.11$ times more likely to have parent reported teeth in fair or poor condition.

Gurunathan et al. (2016) ${ }^{25}$

India

478

Dental neglect

Assessment of oral health Oral hygiene index, DMFT, PUFA (pulp, ulcers, fistula, Main Outcomes

A significant higher dental neglect score was reported among the people who reside in the suburban location $(P$ $<$ 0.001), parents whose educational qualification was

\begin{tabular}{|c|c|}
\hline Study/year & Smitt et al. $(2017)^{6}$ \\
\hline Origin & Netherlands \\
\hline Sample (N) & 376 children (202 males; $54 \%$ ) \\
\hline Age group (years) & $2-17$ \\
\hline Type of violence assessed & $\begin{array}{l}\text { Domestic violence and child abuse from database of a } \\
\text { Social Service. }\end{array}$ \\
\hline Assessment of oral health & $\begin{array}{l}\text { Child who underwent multiple tooth extractions under } \\
\text { general anesthesia }\end{array}$ \\
\hline Main Outcomes & $\begin{array}{l}\text { In } 13 \% \text { of the children multiple tooth extraction took } \\
\text { place before they were reported to a social service. } \\
\text { Additionally, the average time interval between tooth } \\
\text { extraction and reporting was } 36 \text { months (6-91 months). }\end{array}$ \\
\hline Study/year & Kabani et al. (2018) ${ }^{29}$ \\
\hline Origin & USA \\
\hline Sample (N) & 61.530 \\
\hline Age group (years) & $1-17$ \\
\hline Type of violence assessed & $\begin{array}{l}\text { ACEs, including exposure to a parental divorce, parental } \\
\text { death, domestic violence, parental drugs/alcohol } \\
\text { exposure, parental mental illnesses, parental } \\
\text { incarceration, neighborhood violence, household } \\
\text { financial hardship, racial/ ethnic discrimination, and } \\
\text { unfair treatment. }\end{array}$ \\
\hline Assessment of oral health & Question about oral related quality of life \\
\hline Main Outcomes & $\begin{array}{l}\text { Overall, } 18.3 \text { percent of the sample experienced untreated } \\
\text { oral health-care needs morbidity. The sample's exposure } \\
\text { to our refined eight key independent variables, ACEs, } \\
\text { ranged from } 3 \%-50 \% \text {. }\end{array}$ \\
\hline Study/year & Kvist et al. (2018) ${ }^{16}$ \\
\hline Origin & Sweden \\
\hline Sample (N) & $\begin{array}{l}86 \text { children in the study population and } 172 \text { matched } \\
\text { controls. }\end{array}$ \\
\hline Age group (years) & mean age $8.9 \pm 4.3$ \\
\hline Type of violence assessed & $\begin{array}{l}\text { Physical abuse, psychological abuse, intimate partner } \\
\text { violence, sexual abuse, and neglect. }\end{array}$ \\
\hline Assessment of oral health & $\begin{array}{l}\text { Oral hygiene, dietary habits, decayed teeth (DMFT, dmft, } \\
\text { early childhood caries) }\end{array}$ \\
\hline Main Outcomes & $\begin{array}{l}\text { Four factors indicated a high probability of being } \\
\text { investigated because of suspected CAN: prevalence of } \\
\text { dental caries in primary teeth }(\mathrm{OR}=3.92) \text {, fillings in } \\
\text { permanent teeth }(\mathrm{OR}=2.88) \text {, dental health service } \\
\text { avoidance }(\mathrm{OR}=12.37) \text {, and referral to specialist pediatric } \\
\text { dentistry clinics }(\mathrm{OR}=6.13) \text {. }\end{array}$ \\
\hline Study/year & Silva-Júnior et al. (2018) ${ }^{23}$ \\
\hline Origin & Brazil \\
\hline Sample (N) & $\begin{array}{l}48 \text { child abuse victims and } 144 \text { public and private school } \\
\text { students. }\end{array}$ \\
\hline Age group (years) & $8-10$ \\
\hline Type of violence assessed & $\begin{array}{l}\text { Sexual abuse, physical abuse, psychological abuse, and } \\
\text { neglect }\end{array}$ \\
\hline Assessment of oral health & Oral health related quality of life \\
\hline Main Outcomes & $\begin{array}{l}\text { After adjustment for confounding variables, multiple } \\
\text { linear regression showed that child abuse victims } \\
\text { exhibited higher scores on the CPQ overall scale } \\
(P=0,029) \text { and on the oral symptoms and functional } \\
\text { limitations }(P=0,003) \text { subscales with statistical } \\
\text { significance. }\end{array}$ \\
\hline
\end{tabular}

DMFt /dmft: index or decayed, missing, and filled teeth/same for deciduous; DMFS: decayed, missing, and filling surfaces; ECC: early childhood caries; ACEs: adverse childhood experiences.
The type of violence mostly assessed was child physical abuse (CPA), physical neglect, sexual abuse, intimate partner violence (IPV) and childhood adverse experiences (ACE), which included exposure to parental divorce, death, parental use of drugs/alcohol, parental incarceration or mental health. Oral health assessments varied across studies. DMFT/dmft indexes were the most common form of evaluation, identified in eight of them ${ }^{15,16,16,19-23,28}$. Moreover, two studies evaluated oral health conditions through selfperceived oral health ${ }^{8,18}$. Oral health related quality of life was measured in two studies ${ }^{5,27}$. In one study, oral health was evaluated by means of teeth with suspicious areas and gums diseases ${ }^{25}$.

Finally, another study evaluated children who underwent multiple extractions under general anesthesia ${ }^{10}$. Regarding the association between exposure to violence in childhood/adolescence and poor oral health conditions, all studies found that the odds of having oral health problems, poor self-perceived oral health or poor oral health related quality was higher among children who suffered some type of abuse, neglect or suffered some adverse childhood experience (Table 1).

We grouped studies according to oral health outcomes, type of violence participants were exposure and additional findings to identify covariables possibly mediating the associations found in selected studies. Sociodemographic variables (financial hardship, parents' education, gender), type of abuse, number of ACEs, general health, reason of the last consultation, parents' health condition, treatment under general anesthesia influenced some associations found between cases and controls. These results are presented in Chart 1.

Chart 1. Oral health problems according to types of violence reported and additional findings.

\begin{tabular}{|c|c|c|}
\hline $\begin{array}{l}\text { ORAL HEALTH } \\
\text { PROBLEMS }\end{array}$ & $\begin{array}{l}\text { TYPES OF } \\
\text { VIOLENCE } \\
\text { ASSOCIATED }\end{array}$ & COVARIATES \\
\hline \multirow{3}{*}{$\begin{array}{l}\text { CARIES } \\
\text { EXPERIENCE } 4,18-_{20}\end{array}$} & ABUSE/NEGLECT & $\begin{array}{l}\text { Age, rank, family size, and abuse status } \\
\text { had direct relationship with caries } \\
\text { experience. }\end{array}$ \\
\hline & $\begin{array}{l}\text { ADVERSE } \\
\text { CHILDHOOD } \\
\text { EXPERIENCES } \\
\text { (ACES) }\end{array}$ & $\begin{array}{l}\text { There was a graded association between } \\
\text { number of ACEs and likelihood of } \\
\text { caregiver report of having teeth in fair or } \\
\text { poor condition. Children whose parents } \\
\text { reported more than one ACE were more } \\
\text { likely to have parent-reported teeth in } \\
\text { fair or poor condition. }\end{array}$ \\
\hline & $\begin{array}{c}\text { PHYSICAL } \\
\text { ABUSE, } \\
\text { EMOTIONAL } \\
\text { ABUSE, SEXUAL } \\
\text { ABUSE, OR } \\
\text { NEGLECT }\end{array}$ & $\begin{array}{l}\text { Children subject to child protection plans } \\
\text { had significantly higher levels of dental } \\
\text { caries in the primary dentition. }\end{array}$ \\
\hline $\begin{array}{l}\text { POOR ORAL } \\
\text { (GLOBAL) AND } \\
\text { GENERAL } \\
\text { HEALTH }^{27}\end{array}$ & $\begin{array}{l}\text { PHYSICAL } \\
\text { ABUSE, SEXUAL } \\
\text { ABUSE AND } \\
\text { NEGLECT }\end{array}$ & $\begin{array}{l}\text { Neglected children were also at increased } \\
\text { risk for diabetes, poorer lung functioning, } \\
\text { and vision problems. Childhood social } \\
\text { class in part explained increases in the } \\
\text { risk for malnutrition, peak airflow, oral } \\
\text { health, and vision problems in adulthood. }\end{array}$ \\
\hline $\begin{array}{l}\text { POOR ORAL } \\
\text { HEALTH } \\
\text { RELATED } \\
\text { QUALITY OF } \\
\text { LIFE }^{29}\end{array}$ & $\begin{array}{l}\text { ADVERSE } \\
\text { CHILDHOOD } \\
\text { EXPERIENCES }\end{array}$ & $\begin{array}{l}\text { Nearly half of the participants reported } \\
\text { their family was experiencing financial } \\
\text { hardship. Roughly, } 20 \text { percent of the } \\
\text { population reported exposure to parental } \\
\text { divorce during their pediatric } \\
\text { developmental years. }\end{array}$ \\
\hline
\end{tabular}


Chart 1 (Continuation). Oral health problems according to types of violence reported and additional findings.

\begin{tabular}{|c|c|c|}
\hline $\begin{array}{l}\text { ORAL HEALTH } \\
\text { PROBLEMS }\end{array}$ & $\begin{array}{l}\text { TYPES OF } \\
\text { VIOLENCE } \\
\text { ASSOCIATED }\end{array}$ & COVARIATES \\
\hline \multirow{3}{*}{$\begin{array}{l}\text { POOR SELF- } \\
\text { PERCEIVED } \\
\text { ORAL } \\
\text { HEALTH4,22,23 }\end{array}$} & $\begin{array}{l}\text { CHILD PHYSICAL } \\
\text { ABUSE, INTIMATE } \\
\text { PARTNER } \\
\text { VIOLENCE } \\
\text { FORCED SEX AND } \\
\text { BULLYING. } \\
\end{array}$ & $\begin{array}{l}\text { Parents separated, both parents foreign } \\
\text { born and one parent unemployed or on } \\
\text { sick leave were significantly associated. } \\
\text { Boys rated their oral health as poor, or } \\
\text { very poor, significantly more often than } \\
\text { did girls. }\end{array}$ \\
\hline & $\begin{array}{l}\text { SEXUAL ABUSE, } \\
\text { PHYSICAL ABUSE, } \\
\text { PSYCHOLOGICAL } \\
\text { ABUSE, AND } \\
\text { NEGLECT }\end{array}$ & $\begin{array}{l}\text { Child abuse victims exhibited higher } \\
\text { scores on negative self-perception (oral } \\
\text { symptoms and functional limitations } \\
\text { subscales) with statistical significance. }\end{array}$ \\
\hline & $\begin{array}{l}\text { ADVERSE } \\
\text { CHILDHOOD } \\
\text { EXPERIENCES } \\
\text { (ACEs) }\end{array}$ & $\begin{array}{l}\text { There was a graded association between } \\
\text { number of ACEs and likelihood of } \\
\text { caregiver report of having teeth in fair or } \\
\text { poor condition. Children whose parents } \\
\text { reported more than one ACE were more } \\
\text { likely to have parent-reported teeth in fair } \\
\text { or poor condition. }\end{array}$ \\
\hline \multirow{4}{*}{ TOOTH DECAY } & NEGLECT & $\begin{array}{l}\text { Significant associations were found } \\
\text { between caries experience and reason of } \\
\text { the last consultation, decayed teeth and } \\
\text { child's oral health perception. There was a } \\
\text { trend towards a significant association } \\
\text { between general health and decayed teeth, } \\
\text { general hygiene and caries experience, and } \\
\text { caries experience and number of times the } \\
\text { child brushes the teeth. }\end{array}$ \\
\hline & NEGLECT & $\begin{array}{l}\text { There was no significant difference in } \\
\text { dental neglect with respect to sex, age, and } \\
\text { income. With respect to dental neglect, a } \\
\text { significant higher dental neglect score was } \\
\text { reported among the people who reside in } \\
\text { the suburban location, parents whose } \\
\text { educational qualification was secondary, } \\
\text { and those people who have not availed any } \\
\text { dental service for }>3 \text { years. }\end{array}$ \\
\hline & $\begin{array}{l}\text { ABUSED } \\
\text { CHILDREN }\end{array}$ & $\begin{array}{l}\text { Number of missing teeth was also } \\
\text { significantly higher in abused children }\end{array}$ \\
\hline & $\begin{array}{l}\text { DOMESTIC } \\
\text { VIOLENCE AND } \\
\text { CHILD ABUSE }\end{array}$ & $\begin{array}{l}\text { In } 13 \% \text { of the children, multiple tooth } \\
\text { extraction took place before they were } \\
\text { reported to social service. }\end{array}$ \\
\hline $\begin{array}{l}\text { POOR ORAL } \\
\text { HEALTH AND } \\
\text { RISKY RELATED } \\
\text { BEHAVIOR' }\end{array}$ & $\begin{array}{l}\text { PHYSICAL ABUSE, } \\
\text { PSYCHOLOGICAL } \\
\text { ABUSE, INTIMATE } \\
\text { PARTNER } \\
\text { VIOLENCE, } \\
\text { SEXUAL ABUSE } \\
\text { AND NEGLET. }\end{array}$ & $\begin{array}{l}\text { Children under investigation for suspected } \\
\text { CAN had poorer oral hygiene with more } \\
\text { dental plaque as well as more gingivitis } \\
\text { and more irregular dietary habits than } \\
\text { controls. The study group also had } \\
\text { significantly more descriptions of dental } \\
\text { behavior management problems in their } \\
\text { records, more treatment under general } \\
\text { anesthesia and more sedation. }\end{array}$ \\
\hline MALOCCLUSION ${ }^{26}$ & $\begin{array}{l}\text { ABUSED } \\
\text { CHILDREN }\end{array}$ & $\begin{array}{l}\text { Victims of child abuse had worse oral } \\
\text { health reflected by a higher incidence of } \\
\text { decayed teeth, missing primary teeth, } \\
\text { filled permanent teeth, DMFT index, and } \\
\text { anterior open bite. }\end{array}$ \\
\hline $\begin{array}{c}\text { EARLY } \\
\text { CHILDHOOD } \\
\text { CARIES (ECC) }{ }^{17}\end{array}$ & $\begin{array}{c}\text { CHILD } \\
\text { MALTREATMENT } \\
\text { (ABUSE, } \\
\text { NEGLECT) }\end{array}$ & $\begin{array}{l}\text { The proportion of children with severe } \\
\text { ECC tended to be higher in } \\
\text { physically/sexually abused children than } \\
\text { in neglected children. The age distribution } \\
\text { was similar in cases of neglect occurred } \\
\text { among } 4 \text { to 6-year-old children. Only four } \\
\text { children had clinical evidence of dental } \\
\text { injury, recorded in the dental }\end{array}$ \\
\hline
\end{tabular}

\section{- Quality of individual studies}

The results of the NOS for the quality of the included studies are presented in Figure 2. Cross-sectional studies were of slightly better quality than case-control studies (median [range] NOS, $6^{4-8}$ vs. $5^{4-6}$, respectively). Only four studies evaluated the outcome of interest ${ }^{20}$. No study reached the maximum score.

\begin{tabular}{|c|c|c|c|c|}
\hline Study/Year & Selection & Comparability & Exposure & Total \\
\hline \multicolumn{5}{|l|}{ Case-control studies } \\
\hline Greene et al. (1994)19 & 3 & 1 & 1 & 5 \\
\hline Greene et al. $(1995)^{18}$ & 4 & 1 & 1 & 6 \\
\hline Duda et al. $(2017)^{26}$ & 4 & 1 & 1 & 6 \\
\hline Keene et al. (2015) ${ }^{20}$ & 2 & 1 & 1 & 4 \\
\hline \multicolumn{5}{|l|}{ Cohort studies } \\
\hline Widom et al. (2012) ${ }^{27}$ & 3 & 1 & 2 & 6 \\
\hline \multicolumn{5}{|l|}{ Cross-sectional studies } \\
\hline Valencia-Rojas et al. $(2008)^{17}$ & 2 & 2 & 2 & 6 \\
\hline Kvist, et al. $(2013)^{22}$ & 4 & 2 & 2 & 8 \\
\hline Lourenço et al. $(2013)^{24}$ & 2 & 2 & 1 & 5 \\
\hline Bright et al. (2015) ${ }^{4}$ & 3 & 1 & 3 & 7 \\
\hline Gurunathan et al. (2016) 25 & 3 & 1 & 2 & 6 \\
\hline Smitt et al. $(2017)^{6}$ & 3 & 0 & 1 & 4 \\
\hline Kabani et al. (2018) & 2 & 1 & 2 & 5 \\
\hline Kvist, et al. (2018) & 3 & 2 & 2 & 7 \\
\hline Silva-Júnior et al. $(2018)^{23}$ & 3 & 2 & 2 & 7 \\
\hline
\end{tabular}

Figure 2. Quality of individual studies (modified version of the Newcastle-Ottawa Scale)

\section{DISCUSSION}

All studies included in this review found a higher risk or likelihood of some oral health problem associated with domestic violence exposure, comprising physical abuse, emotional abuse, sexual abuse, neglect, or adverse childhood experiences. The main oral health problems reported were caries experience (decayed, missing and filled teeth), poor selfperceived oral health, decayed teeth, malocclusion, poorer oral health related quality of life, poorer oral hygiene, and early childhood caries experience. These results are despite variations in the types of settings included, the study duration, type of study and the measures employed.

Among factors cited, having been subjected to a protection plan $^{16}$, financial hardship/parental divorce ${ }^{25,27}$, low parental education $^{20}$, poorer general health ${ }^{19}$ and poorer oral hygiene were ${ }^{22}$ cited as potential contributors. In fact, social factors linking adverse experiences to poor dental health can include family routines and functioning and parental attitudes toward oral health. Chronic stress is often associated with socially disadvantaged families and can be an underlying mechanism regarding the prevalence of health concerns, including dental caries, in these children ${ }^{29}$. One study identified that family size is a risk factor the presence of untreated, decayed teeth ${ }^{15}$.

A recent systematic review demonstrated that socioeconomic status (SES), parental education, oral health knowledge, and attitudes were associated with early childhood caries in children. To date, most of studies in developing countries have reported distal parental factors such as income and education being significant risk factors in caries development compared to proximal risk factors in low-income groups ${ }^{30}$. There is great difficulty in studying the theme of neglect because it does not easily separate attitudes of abuse and precarious living conditions.

In one prospective longitudinal study ${ }^{25}$, the authors investigated a cohort of people born in sixties and seventies, who suffered from physical abuse, sexual abuse, and neglect. The domestic violence against children interferes in the psychological development leading to sequels that manifest and persist up to the adulthood. The physical evidences of domestic violence are more easily observed in the orofacial complex, becoming eventually detected by dentists. A topic of interest in a recent systematic review was the knowledge of dentists about clinical cases of domestic violence against 
children. Most of dentists receives little or no education about violence during the under graduation in dentistry ${ }^{31}$.

Widom et al. ${ }^{25}$ also reported that neglected children were at increased risk for diabetes, poorer lung functioning, and vision problems. Physical abuse increased risk for diabetes and malnutrition. Sexual abuse showed non-significant trends for hepatitis C, HIV, and oral health. In his study, childhood social class in part explained increases in the risk for malnutrition, peak airflow, and oral health and vision problems in adulthood. Nonetheless, it is likely that behaviors, lifestyle factors, access to health care, and neighborhood characteristics (e.g., environmental toxins) may act as mediators between childhood abuse and neglect and long-term physical health consequences.

In another study, the authors hypothesized that those children who underwent multiple tooth extractions for caries under general anesthesia were abused, in comparison to the normal population. They found a strong association between severe dental caries and child abuse. Furthermore, in some children, the multiple tooth extraction was performed before child abuse and neglect was established ${ }^{10}$.

The results of one study identified ACEs having a statistically significant negative impact on oral health related quality of life (OHRQoL). In comparison to other research, this exploratory study further supports the inverse association between ACEs and OHRQoL. In addition, this study contributed to original evidence on financial hardship being the leading, and practically significant, ACE that public health professions should address when prioritizing interventions ${ }^{27}$.

Dental neglect is willful failure of parent or guardian to seek and follow through with treatment necessary to ensure a level of oral heath essential for adequate function and freedom from pain and infection ${ }^{32}$. While failure/delay in seeking care with adverse dental consequences is highlighted, differentiating dental caries from dental neglect is difficult, and there is a paucity of data on precise clinical features to aid in this distinction. Domestic violence is a difficult issue to investigate, so studies look after social services databases to retrieve information.

To the best of our knowledge, this is the first review to investigate the relationship between domestic violence perpetrated against children and adolescents and oral health problems. Our results indicate that all types of domestic violence have some negative impact on oral health, despite the type of abuse perpetrated. While we have attempted to follow a rigorous protocol in the conduct of this review, it is still subject to several limitations. It may be prone to indexing bias, publication bias and reporting bias. Our ability to assess quality of the studies that we identified was limited by the methodological information provided in the published articles, some of which was incomplete.

The findings from this review represents the experiences of children and adolescents aged 0 to 18 years from different countries. Understanding the mechanisms that place abused and neglected children at higher risk for these adult physical health outcomes will help focus these efforts. Having only one ACE was associated with a slight increase in likelihood of having poor dental health; the combination of three or more ACEs, however, more than doubled the likelihood ${ }^{8}$.

CONCLUSION

Exposure to domestic violence can pose children to an increased risk of having poor oral health. The main oral health problems and negative behaviors associated are caries experience (decayed, missing and filled teeth), poor self-perceived oral health, malocclusion, poorer oral health related quality of life, poorer oral hygiene, and early childhood caries experience. Methodological advancements in determining exposure to violence, selection of control groups, and neglect definitions are needed to improve comprehension on this theme.

\section{REFERENCES}

1. Okunseri C, Gonzalez C, Hodgson B. Children's Oral Health Assessment, Prevention, and Treatment. Pediatr Clin North Am. 2015;62(5):1215-26.

2. Blanco-Aguilera a, Blanco-Hungría a, BiedmaVelázquez L, Serrano-Del-Rosal R, GonzálezLópez L, Blanco-Aguilera E, et al. Application of an oral health-related quality of life questionnaire in primary care patients with orofacial pain and temporomandibular disorders. Med Oral Patol Oral Cir Bucal. 2014;19(2):e127-35.

3. Arman K, Petruninaite A, Grigalauskiene R, Slabsinskiene E, Petruninaitè A, Grigalauskienè $R$, et al. Stress experience and effect on selfperceived oral health status among high school students. Stomatologija. 2016;18(3):75-9.

4. Wagner $Y$, Heinrich-Weltzien R. Risk factors for dental problems: Recommendations for oral health in infancy. Early Hum Dev. 2017;114: 16-21.

5. Da Silva-Júnior IF, Hartwig AD, Stüermer VM, Demarco GT, Goettems ML, Azevedo MS. Oral 
health-related quality of life in Brazilian child abuse victims: A comparative study. Child Abus Negl. 2018;76:452-8.

6. Zou J, Meng M, Law CS, Rao Y, Zhou X. Common dental diseases in children and malocclusion. Int J Oral Sci. 2018;10(1):1-7.

7. Wilson PhD, MSN, RN, IBCLC, AHN-BC, C DR. Health Consequences of Childhood Sexual Abuse. Perspect Psychiatr Care. 2010; 46(1):56-64.

8. Bright MA, Alford SM, Hinojosa MS, Knapp C, Fernandez-Baca DE. Adverse childhood experiences and dental health in children and adolescents. Community Dent Oral Epidemiol. 2015;43(3):193-9.

9. Wegman HL, Stetler C, Ångerud K, Annerbäck EM, Tydén T, Boddeti S, et al. Characteristics of child dental neglect: A systematic review. J Dent. 2019;62(5):229-39.

10. Sillevis Smitt $H$, de Leeuw J, de Vries $T$. Association Between Severe Dental Caries and Child Abuse and Neglect. J Oral Maxillofac Surg. 2017;75(11):2304-6.

11. Weijs C, Lang R, Lorenzetti DL, Milaney K, Figueiredo R, Smith LB, et al. The Relation Between Exposure to Intimate Partner Violence and Childhood Dental Decay: A Scoping Review to Identify Novel Public Health Approaches to Early Intervention. J Can Dent Assoc. 2019;84(C):j5

12. Krug EG, Mercy JA, Dahlberg LL et. al. World report on violence and health - World Health Organization. Lancet. 2002;360:1083-8.

13. Leite JT, Beserra MA, Scatena L, Silva LMP da, Ferriani $M$ das GC. Coping with domestic violence against children and adolescents from the perspective of primary care nurses. Rev Gauch Enferm. 2016;37(2):e5579-6.

14. Moher D, Liberati A, Tetzlaff J, Altman DG, Altman D, Antes $G$, et al. Preferred reporting items for systematic reviews and metaanalyses: The PRISMA statement. PLoS Med. 2009;67.

15. Greene PE, Chisick MC, Aaron GR. A comparison of oral health status and need for dental care between abused/neglected children and nonabused/non-neglected children. Pediatr Dent. 1994;16(1):41-5.

16. Keene EJ, Skelton R, Day PF, Munyombwe T, Balmer RC. The dental health of children subject to a child protection plan. Int $\mathrm{J}$ Paediatr Dent. 2015;25(6):428-35.

17. Gilbert R, Widom CS, Browne K, Fergusson D, Webb E, Janson $S$, et al. Burden and consequences of child maltreatment in highincome countries. Lancet. 2009;373(8):68-81.

18. Kvist T, Annerbäck EM, Sahlqvist L, Flodmark O, Dahllöf G. Association between adolescents' self-perceived oral health and self-reported experiences of abuse. Eur $\mathrm{J}$ Oral Sci. 2013;121(6):594-99.
19. Lourenço CB, Saintrain MV de L, Vieira APGF. Child, neglect and oral health. BMC Pediatr. 2013;13(1).

20. Gurunathan D, Shanmugaavel AK. Dental neglect among children in Chennai. J Indian Soc Pedod Prev Dent. 2016;34(4):364-9.

21. Duda JG, Biss SP, Bertoli FM de P, Bruzamolin $\mathrm{CD}$, Pizzatto E, Souza JF, et al. Oral health status in victims of child abuse: a case-control study. Int J Paediatr Dent. 2017;27(3):210-6.

22. Kvist T, Annerbäck EM, Dahllöf G. Oral health in children investigated by Social services on suspicion of child abuse and neglect. Child Abus Negl [Internet]. 2018;76:515-23.

23. Valencia-Rojas N, Lawrence HP, Goodman D. Prevalence of early childhood caries in a population of children with history of maltreatment. J Public Health Dent. 2008;68(2):94-101.

24. Greene, Patrice LTC Chisick ML. Child Abuse/Neglect and the Oral Health of Children's Primary Dentition. Child Abus Oral Heal. 1995;160:290-3.

25. Widom CS, Czaja SJ, Bentley T, Johnson MS. A prospective investigation of physical health outcomes in abused and neglected children: New findings from a 30-year follow-up. Am J Public Health. 2012;102(6):1135-44.

26. Greene PE, Chisick MC, Aaron GR, Widom CS, Czaja SJ, Bentley T, et al. A comparison of oral health status and need for dental care between abused/neglected children and nonabused/nonneglected children. Community Dent Oral Epidemiol. 2012;43(11):2304-6.

27. Kabani F, Lykens K, Tak HJ. Exploring the relationship between adverse childhood experiences and oral health-related quality of life. J Public Health Dent. 2018;78(4):313-20.

28. Greene PL, Chisick MC. Child Abuse/Neglect and the Oral Health of Children's Primary Dentition. 1995;160:290-3.

29. Pani SC, Abuthuraya D, Alshammery HM, Alshammery D, Alshehri $\mathrm{H}$. Salivary cortisol as a biomarker to explore the role of maternal stress in early childhood caries. Int $\mathrm{J}$ Dent. 2013;2013.

30. Rai NK, Tiwari T. Parental factors influencing the development of early childhood caries in developing nations: A systematic review. Front Public Heal. 2018;6:1-8.

31. Rodrigues JLSA, Lima APB, Nagata JY, Rigo L, Cericato GO, Franco A, et al. Domestic violence against children detected and managed in the routine of dentistry - A systematic review. J Forensic Leg Med. 2016;43:34-41.

32. Bhatia SK, Maguire SA, Chadwick BL, Hunter ML, Harris JC, Tempest V, et al. Characteristics of child dental neglect: A systematic review. J Dent. 2014;42(3):229-39. 


\section{CONFLICTS OF INTERESTS}

The authors declare no conflicts of interests.

\section{CORRESPONDING AUTHOR}

Nataly Pereira da Costa

Department of Dentistry, Division of Hebiatrics, University of Pernambuco, Recife, Brazil.

Rua Roberval Luna de Oliveira, 825,

54762-740 Camaragibe - Centro, Recife - PE, Brasil

E-mail: nataly.pcosta@hotmail.com

Received 08/03/2021

Accepted 16/07/2021 